\title{
Customers Perceptions toward the Use of Online Services: The Case of Saudi Telecommunication Sector
}

\author{
Abdullah A.S, AL-Shourah \\ Department of Management Faculty of Finance and Business \\ The World Islamic University for Sciences \& Education WISE, Jordan \\ Tel: 962-772-426-996_E-mail: al_shourah@yahoo.com
}

Received: Dec. 8, 2013 Accepted: January 29, 2014 Published: January 29, 2014

doi:10.5296/jmr.v6i1.4695 URL: http://dx.doi.org/10.5296/jmr.v6i1.4695

\begin{abstract}
The consumer attitudes perceptions toward online services can help marketing managers predict the online services rate and evaluate the future growth of commerce. In general, the research expected to contribute to the theory and practice of consumer behavior consumer perceptions toward online services. This research intends to propose framework that will implementing the consumer perceptions towards online service dimensions, mainly, (perceived usefulness, and perceived ease of use, perceived enjoyment, and privacy security) that is compatible with the Saudi telecommunication companies. The objective of this study are to test the framework, structural equation modeling techniques have been applied to data collected from 102 customers of telecommunication sector in Saudi Arabia. Therfor the result build that the factors affects the consumer perceptions towards online service, thus all of these factors enhance the ability of the consumer to handle the products or services and search them through the internet. Additional, there is statistically significant effect the factors consumer perceptions towards online service at Saudi telecommunication sector.
\end{abstract}

Keywords: Customers, Attitudes, Perceptions, Toward, Online Services 


\section{Introduction}

Technology in general has been an important channel for companies to provide product information and offer direct sales to their customers. Though at the same time technology has provided both companies and consumers with helpful means to handle their decision making problems, among other things, well; internet can be easily accessed by users in order to attain information about anything they want including various products of vendors (Lin \& Hong 2006). The practice of the internet as a communication and business in consumer markets is growing rapidly. In line with this expansion, consumer-based electronic commerce has become an emerging research area (Teo, 2006). In particular, a stream of research addressing issues related to online services and customers. The importance of online services for organizations is becoming generally customary across both industrial and service sectors.

The internet benefits do not stop here, rather, companies use the internet for many purposes such as to improve their products and services to consumers; as a matter of fact companies can establish a wide variety of businesses online, this type of business is called e-commerce and the level of consumer perceptions towards online services (Lin \& Hong, 2006). In regard to consumer's behavior on the internet, there are many factors that influence consumer purchasing decision making whether in real- life or online. Consequently, consumer decision making in online services is influenced by societal factors in particular (Joon Moon, 2004), personal and impersonal information sources also influence, consumer decision making (Senecal and Nantel, 2004).

Doubts are raised on relevant issues such as knowledge and skills the level of consumer perceptions towards online services, accessing the internet services, online companies promotions, security measures in protecting onlin services. In fact, this phenomenon raises serious concerns in consumer behavior (Alsmadi, 2002). Therefore, the researcher hopes that this study will contribute to the literature of customers perceptions toward in general and online consumer behavior in particular through identifying factors that affect the Saudi telecommunication sectors.

\subsection{Research Problem}

The developed of system online services had been produced and developed gradually, forming new business model and business possibility which exerted an important influence on the country is economic future development and international competitiveness. Information technology affects everything from daily life to business in the $21^{\text {st }}$ century. The quality factors of electronic commerce sites in terms of information, agreement, and settlement phases. They also review those factors related to e-commerce community. This study will examine the most important aspects of online services from customer point view, and what factors that influence consumers perceptions toward online services at telecommunication sector in Saudi, specifically, this study attempt to answer the two following questions:

1- How customers perceptions toward the use of online services? 
2- Are the consumer's perceptions toward online services moderated by personal demographic variables?

\subsection{Research Objectives}

This research expected to contribute to the theory and practice of consumer behavior consumer perceptions toward online services, and the use of technology in general. By answering the research questions, the study seeks to achieve the following research objectives:

- To add to the new literature relating to consumer behavior with regards to use of technology.

- To understand the consumer's perception toward online services.

- To identify the quality dimensions of online services from consumer point view.

\section{Literature Review}

\subsection{Customers Perceptions Toward}

The combination of the Internet, plus physical presence, provides more opportunities to capture business than the online-only presence, because they can offer better pre-purchase and post-sales services to lower consumer deal cost and build trust in online stores (Gefen et al. 2003; Yu, 2008). In addition consumers perceptions toward online services can also be defined as "The sale and purchase of products and services over the Internet, which includes sharing business information, maintaining business relationships and carry out business communication by way of internet-based technology" (Hsu, 2006). Consumers and businesses have the ability to shop from their homes or offices for a variety of products and services from all over the world. Consumers are able to view products on their computers, and visualize how the products may benefit their needs (Kotler \& Armstrong, 2000). Moreover, the benefit of online services over traditional marketing can be summarize by increased speed and competence, lower progressing costs, 24 hour service, quick adjustment to market situations and the ability to deal with consumers directly instead of through intermediaries (Hsu, 2006).

Magee (2003) note that the growth in the number of online services is greater than the growth in internet users, indicating that more internet users are becoming easy to serve online. Moreover, they are now able to access the Internet, not only from their personal computers, but from advanced electronic devices such as mobile phones (Kau et al. 2003). The important consumer advantage linked with services on the web is the contact to greater amounts of dynamic information to support queries for consumer decisions (Shim et al. 2001).

Keng et al. (2007) showed that privacy, security, convenience and experience were significantly influenced consumer perceptions on online ticketing, while trust factor was not significantly influenced consumer perceptions on online ticketing. Zeithaml et al. (2000) focus in has study, that companies should focus on online service surrounding all cues and meet that occur before, during, and after the dealings. Other studies have famous key 
dimensions of online service in the context of only just defined online businesses, such as banks, portal services, and travel agencies (Chiang \& Dholakia, 2003).

An additional possible benefit of using the internet is the ability to gather information about your consumers via surveys and contests (Rendleman, 2001). The information can be use to assist new product development and introduction (Higgins, 2001). Companies can design and personalize advertising for each consumer through "push" technology. Kim et al. (2003) recognized that attitude consumer perceptions toward online services as an individual characteristic that may play a role in developing perceptions of a specific website. In another study, Lee \& Johnson (2002) examined differences in attitudes consumer perceptions toward online services among different groups of consumers, determined largely by their online browsing and purchasing experiences. Wu (2003) observeed that the relationship between consumer characteristics and attitude consumer perceptions toward online services and formed the influence factors of attitude.

Morimoto \& Chang (2006) requesting to understanding consumer attitudes towards two major direct online services techniques, unsolicited commercial e-mail and postal direct mail. In particular, audience perceptions of advertising intrusiveness, perceived loss of control (as conceptualized by Psychological Reactance), and irritation regarding the direct online services techniques were investigated. Senecal \& Nantel (2004) investigated that consumers' usage of online recommendation sources and their influence on online product choices. Results indicated that subjects who consulted product recommendations selected recommended products twice as often as subjects who did not consult recommendations. Jayawardhena (2004) identified that personal values (self-direction values, enjoyment values and self-achievement values) were significantly related to positive attitudes toward online services. Individual attitudes consumer perceptions toward online services were a direct predicator of online services behavior and mediated the relationship between personal values and behavior.

Smith (2004) suggested that the online services phenomena are governed by a number of factors such as consumer acceptance, behavior, purchasing characteristics, patterns and power. Consequently, Chen \& Chang (2006) found that the consumer did not have direct control over the actions of a seller and in which marketers seek long-term relations with their consumers. Elliott \& Speck (2005) indicated that affect consumer attitude toward a retail web site. In other study found that website reliability/fulfillment, website consumer service and website security/privacy are the four dominant factors which influence consumer perceptions of online services. These buyers have different evaluations of website design and website reliability fulfillment but similar evaluations of website security/privacy issues, which imply that security privacy issues are important to most online buyers (Shergill \& Chen, 2005). Parissa \& Maria (2005) investigated antecedents of consumer attitudes toward advertising via mobile devices. The results indicated that advertising value and advertising message content have the largest impact on attitude toward advertising via mobile devices.

Senecal \& Nantel (2004) investigated that the online recommendation source labeled "recommender system," typical of the personalization possibilities offered by online retailing, 
was more influential than more traditional recommendation sources such as "human experts" and "other consumers". Online shoppers are aware of some of the discouraging features of online services, but these features do not deter them from online services (Yang \& Lester, 2004). Jarvenpaa et al. (2000) investigated how consumers perceived store size and reputation influence their trust in the store, the study discovered that there is a positive relationship between consumer trust in internet stores and the stores perceived reputation and size. Georgiades et al. (2000) indicated that the gender and occupation had an influence only on attitudes concerning perceptions of the competitiveness of the Internet and its impersonal nature. Forthermor, the authors reviewed previous established theories on consumer decision making in offline environments and research findings regarding consumer behavior in an online environment.

\subsection{Onlain Services}

The organizations across the world are realigning their strategies to acquire improvement of this chance and overcome the challenges to the way they control, deliver services and compete with each other using online services (Chan \& Lu, 2004). conceptualized attitudes as "a person's relatively consistent evaluations, feelings and tendencies toward an object or idea". Since attitudes are difficult to change, to understand consumer attitudes perceptions toward online services can help marketing managers predict the online services rate and evaluate the future growth of commerce $(\mathrm{Wu}, 2003)$. In addition, attitude toward online services has a strong influence on consumers' buying intentions, the immediate precursor to actual behavior (Lim \& Dubinsky, 2004). Hence, measuring attitudes toward websites is an important step in studying the effectiveness of website design and web business.

Kim et al. (2003) identified the attitude toward online services as an individual characteristic that may play a role in developing perceptions of a specific website. Shim et al. (2001) found that consumers' positive attitudes toward online services significantly influenced the use of the internet for information searching and intentions to shop online. In another study, Lee \& Johnson (2002) examined differences in attitudes toward online services among different groups of consumers, determined largely by their online browsing and purchasing experiences.

Ha \& Stoel (2009) investigated whether browsing for information intention can be directly linked to a purchasing intention, where online purchasing intention is the act in which consumers actually pay for goods over the Internet. Whether consumers browsing the websites for the purpose of purchase, or browsing just for information search is significantly related to actual online services purchases, which is the ultimate goal of online services businesses based on the previous researches for attitudes toward the web. Moreover, the success of an companies in a culturally different marketplace may be largely determined by how well decision-makers grasp the consumer's buying behavior, and how well the decision-makers incorporate such understanding into their services plans and strategies (Leo et al. 2005).

Online Services: as "the initial landing on the home page until the requested service has been completed or the final product has been delivered and is fit for use" (Boyer Hallowell \& Roth, 
2002). Perceived Usefulness: erceived usefulness is defined as the potential user's individual belief that using definite application system will increase his or her job performance within an organizational context (Hsu, 2006). Perceived Easy of Use: Refers to the level to which the eventual user expects the use of the aim system to be free of effort. PEU is extensive related to intent to adopt Internet Payment, so directly and indirectly via its influence on perceived usefulness (Chan \& Lu, 2004). Perceived Enjoyment: This term describes the physical aspects of a store; such as colors, music type, music volume and tempo and layout of products (East, 1997). Privacy Security: As the amount of products and services accessible via the internet grow speedily, consumers are concerned about security and privacy issues (Hernandez \& Mazzon, 2007).

\section{Research Methodology}

This formulation of the theoretical framework study of the consumer's perception toward online services. Additional, the description the sampling procedure, which includes the data collection method and the variables and measures as well as statistical analytical methods that will be used.

\section{Consumer Perceptions Dimensions}

1. Perceived Usefulness

2. Perceived Easy of use

\section{$\underline{\text { Online Services }}$}

Figure 1. Theoretical Framework Study of the Consumer's Perception Toward The Use of Online Services

\subsection{Study Hypotheses}

The study mainly tests the following hypotheses:

First main hypotheses: There is no statistically significant effect of the influencing factors on consumer's perception toward online services at Saudi Arabia mobiles telecommunication sector.

From this hypothesis the following sub-hypotheses have been derived:

1. There is no statistically significant effect of the perceived usefulness on consumer's perception toward online services at Saudi Arabia mobiles telecommunication sector.

2. There is no statistically significant effect of the perceived ease of use on consumer's perception toward online services at Saudi Arabia mobiles telecommunication sector.

3. There is no statistically significant effect of the perceived enjoyment on consumer's perception toward online services at Saudi Arabia mobiles telecommunication sector. 
There is no statistically significant effect of the security and privacy on consumer's perception toward online services at Saudi Arabia mobiles telecommunication sector.

Second main hypothesis: There are no statistically significant differences in the effect of the influencing factors on consumer's perception toward online services at Saudi Arabia mobiles telecommunication sector due to demographic variables.

\section{Result and Discussion}

The result can be make clear that the factors affects the consumer perceptions towards online service, thus all of these factors enhance the ability of the consumer to handle the products or services and search them through the internet. The perceived usefulness helps the consumer to realize the benefits of the service or products, which affects the attitude of the consumer perceptions towards online service. From the result also, the perceived enjoyment from the service or product enhances and encourage the consumer to re-buy through the internet. Therformore result can be explained by saying that the security and privacy of the information exchanged between the company and the client must be high, in order to increase the consumers' trust in dealing with the company and purchase products through the internet without being afraid of loosing data or information that put them under deception process.

There is statistically significant effect for the influencing factors on consumer perceptions towards online service at Saudi telecommunication sector. Mortherfor there is no statistically significant effect for the perceived usefulness, perceived enjoyment and curity and privacy on consumer perceptions towards online service at Saudi telecommunication sector. Percentaged tables and a chi-square test of independence are also used to study the relationship between the consumer perceptions and the online service factors. 2 detailed hypotheses have been examined by using the percentaged tables and the chi-square tests of independence, each factor was independently tested. Other hypotheses were tested by using multi-linear regression analysis.

In terms of differences, T-test was utilized to examine the differences between online services among male and female. Mean for male was a bit higher than mean for female, with 58.0 and 42.1 respectively. Meanwhile, the One-way ANOVA test was utilized to examine the differences between online services among education background. The study also found that there is a significant difference in attitude towards online services the male and female students $(\mathrm{t}=3.979, \mathrm{p} \leq 0.01)$. The use of laboratory internal consistency (alpha), in order to collect the questionnaires, where the value of (alpha) of the questionnaire (95.6\%) which is excellent because it is higher than $60 \%$, as The value of (alpha) for the independent study variables also higher than the accepted $60 \%$, and is intended variable consistently free of the questions that measured by the accidental errors are shown in Table 1. 


\section{IIl Macrothink}

Table 1. Reliability of Instrument

\begin{tabular}{|l|l|c|}
\hline No. & Field & Alpha \\
\hline 1 & Perceived Usefulness & 0.66 \\
\hline 2 & Perceived Easy of use & 0.60 \\
\hline 3 & Perceived Enjoyment & 0.80 \\
\hline 4 & Perceived Security & 0.64 \\
\hline & Total Stability & 0.86 \\
\hline
\end{tabular}

\subsection{Descriptive Statistics:}

Means and standard deviations of the answers of the study sample of the questionnaire items were calculated, and the following tables show the results of each field of the questionnaire. The result of standard deviations of perceived usefulness can be explained by saying that there are no differences between the services provided by the communication company, whether, it was provided through internet or through the ordinary buying.

The result of perceived easy of use make clear that the attractive and appropriate backgrounds construct no difference in the point of view of the consumer. And this means that the consumers have low trust in the security of their information in the company. This explained the privacy secrecy have nothing to do with the success of the company as long as the company provides a good service.

\subsection{Testing Hypothesis}

The First Main Hypothesis: There is no statistically significant effect of the influencing factors on consumer's perception toward online services at Saudi Arabia mobiles telecommunication sector.

From Table 2. shows that the effect of customers' perceptions aggregated on online services is significant where $\mathrm{F}$ calculated equals to (153.138) wuth ( $\mathrm{Sig}=0.000)$ less than 0.05 . Correlation coefficient $(\mathrm{R}=0.781)$ represents the strength of relationship between two variables which is positive. Moreover, coeficint determinant ( $\mathrm{R}$-squared $=0.610)$ indicates that $61.0 \%$ of variation in online services can be illustrated by the variation of customers' perceptions. Finally, value of coefficient $(0.781)$ is significant value depending on t-value (12.375) and (Sig=0.000) which less than 0.05. 


\section{Macrothink}

Table 2. Result of regression of customers' perception toward online services

\begin{tabular}{|l|l|l|l|l|}
\hline Variables & Coefficients & Std. Error & t-value & Significant \\
\hline Customers' perceptions & 1.038 & 0.084 & 12.375 & 0.000 \\
Constant & -0.154 & 0.286 & -0.537 & 0.593 \\
\hline R correlation & 0.781 \\
R squared & 0.610 \\
F statistics & 153.138 \\
Sig. & 0.000 & \\
\hline
\end{tabular}

H01-1: There is no statistically significant effect of the perceived usefulness on consumer's perception toward online services at Saudi Arabia mobiles telecommunication sector.

From Table 3. shows that the effect of usefulness on online services is significant where $\mathrm{F}$ calculated equals to (34.001) wuth $(\mathrm{Sig}=0.000)$ less than 0.05 . Correlation coefficient $(\mathrm{R}=0.508)$ represent the strength of relationship between two variables which is positive. Moreover, coeficint determinant (R-squared $=0.258$ ) indicates that $25.8 \%$ of variation in online services can be illustrated by the variation of usefulness. Finally, value of coefficient (0.522) is significant value depending on t-value (5.831) and (Sig=0.00) which less than 0.05. Additionally, perceived usefulness helps the consumer to realize the benefits of the service or products, which affects the attitude of the consumer towards onlin services.

Table 3. Result of regression of perceived usefulness toward online services

\begin{tabular}{|l|l|l|l|l|}
\hline Variables & Coefficients & Std. Error & t-value & Significant \\
\hline Usefulness & 0.522 & 0.090 & 5.831 & 0.00 \\
Constant & 1.525 & 0.317 & 4.805 & 0.00 \\
\hline R correlation & 0.508 \\
R squared & 0.258 \\
F statistics & 34.001 \\
Sig. & 0.000 \\
\hline
\end{tabular}

H01-2: There is no statistically significant effect of the perceived ease of use on consumer's perception toward online services at Saudi Arabia mobiles telecommunication sector. 


\section{Macrothink

From Table 4. shows that the effect of easy of use on online services is significant where $\mathrm{F}$ calculated equals to (1093.358) wuth $(\mathrm{Sig}=0.000)$ less than 0.05. Correlation coefficient $(\mathrm{R}=0.958)$ represent the strength of relationship between two variables which is positive. Moreover, coeficint determinant (R-squared $=0.918$ ) indicates that $91.8 \%$ of variation in online services can be illustrated by the variation of easy of use. Finally, value of coefficient (1.066) is significant value depending on t-value (2.704) and (Sig=0.000) which less than 0.05. Furthermore this result is companionable with the result of a study by Elliott \& Speck (2005) which, indicated that ease of use affect consumer attitude toward a retail online services.

Table 4. Result of regression of easy of use toward online services

\begin{tabular}{|l|l|l|l|l|}
\hline Variables & Coefficients & Std. Error & t-value & Significant \\
\hline $\begin{array}{l}\text { Easy of use } \\
\text { Constant }\end{array}$ & 1.066 & 0.112 & 33.066 & 0.000 \\
& 304 & 0.032 & 2.704 & 0.008 \\
\hline R correlation & 0.958 \\
R squared & 0.918 \\
F statistics & 1093.358 & \\
Sig. 0.000 & \\
\hline
\end{tabular}

H01-3: There is no statistically significant effect of the perceived enjoyment on consumer's perception toward online services at Saudi Arabia mobiles telecommunication sector.

From Table 5. shows that the effect of enjoyment on online services is significant where $\mathrm{F}$ calculated equals to (71.684) wuth $(\mathrm{Sig}=0.000)$ less than 0.05 . Correlation coefficient $(\mathrm{R}=0.650)$ represent the strength of relationship between two variables which is positive. Moreover, coeficint determinant (R-squared $=0.422$ ) indicates that $42.2 \%$ of variation in online services can be illustrated by the variation of enjoyment. Finally, value of coefficient (0.627) is significant value depending on t-value (4.250) and (Sig=0.000) which less than 0.05 . This means that there is statistically significant effect of the Perceived enjoyment on consumers' attitudes toward online services. This result is compatible with a study by a Jayawardhena, (2004). 


\section{Macrothink}

Table 5. Result of regression of enjoyment toward online services

\begin{tabular}{|l|l|l|l|l|}
\hline Variables & Coefficients & Std. Error & t-value & Significant \\
\hline $\begin{array}{l}\text { Enjoyment } \\
\text { Constant }\end{array}$ & 0.627 & 0.074 & 8.467 & 0.000 \\
& 1.134 & 0.267 & 4.250 & 0.000 \\
\hline R correlation & 0.650 \\
R squared & 0.422 \\
F statistics & 71.684. \\
Sig. 0.000 & \\
\hline
\end{tabular}

H01-4: There is no statistically significant effect of the security privacy on consumer's perception toward online services at Saudi Arabia mobiles telecommunication sector.

From Table 6. shows that the effect of secutity privacy on online services is significant where $\mathrm{F}$ calculated equals to (10.496) wuth ( $\mathrm{Sig}=0.002)$ less than 0.05 . Correlation coefficient $(\mathrm{R}=0.311)$ represents the strength of relationship between two variables which is positive. Moreover, coeficint determinant $(\mathrm{R}$-squared $=0.097$ ) indicates that $9.7 \%$ of variation in online services can be illustrated by the variation of security privacy.

Finally, value of coefficient (0.300) is significant value depending on t-value (3.240) and $(\mathrm{Sig}=0.002)$ which less than 0.05 . This result shows that the security and privacy of the information replace between the company and the client must be high.

Table 6. Result of regression of security privacy toward online services

\begin{tabular}{|l|l|l|l|l|}
\hline Variables & Coefficients & Std. Error & t-value & Significant \\
\hline Securirty privacy & 0.300 & 0.092 & 3.240 & 0.002 \\
Constant & 2.410 & 0.294 & 8.191 & 0.000 \\
\hline R correlation & 0.311 & \\
R squared & 0.097 \\
F statistics & 10.496 \\
Sig. & 0.002 & \\
\hline
\end{tabular}




\section{Macrothink}

Journal of Management Research

ISSN 1941-899X

2014, Vol. 6, No. 1

Second main hypothesis: There are no statistically significant differences in the effect of the influencing factors on consumer's perception toward online services at Saudi Arabia mobiles telecommunication sector due to demographic variables.

From Table 7. shows that the effect of gender is not significant, where t-value (0.506) with (Sig=0.614) greater than 0.05 . This result might be due to the absence of differences related to gender between the consumers' attitudes toward using the online services.

Table 7. Results the differences testing attri buted to gender

\begin{tabular}{|l|l|l|l|l|}
\hline Variables & Coefficients & Std. Error & t-value & Significant \\
\hline Customers' perceptions & 1.028 & 0.087 & 11.875 & 0.000 \\
Gender & 0.056 & 0.110 & 0.506 & 0.614 \\
Constant & -0.199 & 0.301 & -0.661 & 0.510 \\
\hline R correlation & 0.782 & & \\
R squared & 0.611 & \\
F statistics & 76.116 \\
Sig. & 0.000 & \\
\hline
\end{tabular}

From Table 8. shows that the effect of age is not significant, where t-value (0.270) with $(\mathrm{Sig}=0.788)$ greater than 0.05 . This means that there are no statistically significant differences in the effect of the influencing factors on consumers' attitudes toward online services Saudi telecommunication sector due to age.

Table 8 . Results the differences testing attri buted to age

\begin{tabular}{|l|l|l|l|l|}
\hline Variables & Coefficients & Std. Error & t-value & Significant \\
\hline Customers' perceptions & 1.035 & 0.085 & 12.187 & 0.000 \\
Age & 0.019 & 0.071 & 0.270 & 0.788 \\
Constant & -0.181 & 0.304 & -0.593 & 0.554 \\
\hline R correlation & 0.781 & & \\
R squared & 0.610 & \\
F statistics & 75.881 \\
Sig. & 0.000 & \\
\hline
\end{tabular}




\section{Macrothink}

From Table 9. shows that the effect of income is not significant, where t-value $(-1.469)$ with $(\mathrm{Sig}=0.968)$ greater than 0.05 . This means there are statistically significant differences in the effect of the influencing factors on consumers' attitudes toward online services at Saudi telecommunication sector due to economic status.

Table 9. Results the differences testing attri buted to income

\begin{tabular}{|l|l|l|l|l|}
\hline Variables & Coefficients & Std. Error & t-value & Significant \\
\hline Customers' perceptions & 1.041 & 0.083 & 12.482 & 0.000 \\
Income & -0.063 & 0.043 & -1.469 & 0.145 \\
Constant & -0.012 & 0.300 & -0.040 & 0.968 \\
\hline R correlation & 0.786 \\
R squared & 0.618 \\
F statistics & 78.554 \\
Sig. & 0.000 & \\
\hline
\end{tabular}

From Table 10. shows that the effect of qualification is not significant, where t-value (-1.643) with $(\mathrm{Sig}=0.104)$ greater than 0.05 . This burials that there are no statistically significant differences in the effect of the influencing factors on consumers' attitudes toward online services at Saudi telecommunication sector due to educational qualification.

Table 10. Results the differences testing attri buted to qualification

\begin{tabular}{|l|l|l|l|l|}
\hline Variables & Coefficients & Std. Error & t-value & Significant \\
\hline Customers' perceptions & 1.070 & 0.085 & 12.526 & 0.000 \\
Qualification & -0.079 & 0.048 & -1.643 & 0.104 \\
Constant & -0.073 & 0.288 & -0.254 & 0.800 \\
\hline R correlation & 0.788 & & \\
R squared & 0.620 \\
F statistics & 79.245 \\
Sig. & 0.000 & \\
\hline
\end{tabular}




\section{Conclusion}

The Saudi communication companies should regulate the rules and procedures to keep up with the technological and scientific achievement. Morthanfor its need to develop its care service centers in order to meet the challenges of satisfying the consumers' needs and desires. And extensive culture awareness programs must be established and run by both public and private sectors in order to provide Saudian population with needed information about online service and its benefits. Saudian communication companies must make their internet presence more effective by offering multiple incentive programs for their online consumers and by offering their services in lower prices on the internet.

This study has taken important steps to investigate the attitude towards online services and the factors affecting the attitude towards online servicces. Despite this study has strengths, it has certain limitations. First, the limitation of the data prevents further exploration of the study. There were only 102 respondents whom have been participated in this study using convenience sampling. Future researchers are suggested to implement more representativeness sampling method and increasing the sample size variety especially in respondents' age to decrease the error for the purpose of the generalizing result to a wider population. Second, future researchers may further scope to replicate the study in different environment and different geographical locations.

\subsection{Recommendation}

Furthermore this research has only examines four factors that influence online servecse. Future researchers are suggested to determine other factors that influence online services beside the socio-demographic. Therefore, it can help them to understand other factors that may influence the online services. From previous mentioned studies, we can see that online services has the probable to offer business companies both short-term and long-term benefits.

\section{References}

Al Smadi, S. (2002). Consumer attitudes toward online shopping in Jordan: opportunities and challenges. The 1st Marketing Conference, U.A.E.

Bellman, S., G. Lohse, \& Johnson, E. (2000). Predictors of online buying behavior. Communications of the ACM., 12, 32-38.

Boyer, K.R., Hallowell, \& Roth, A. V. (2002). E-services: operating strategy - a case study and method for analysing operational benefits. J. Operations Management, 20.

Case, T., Burns, O. M., \& Dick, G. N. (2001). Drivers of on-line purchasing among U.S. university students. Proceedings of the 7th Americas Conference on Information Systems, Boston.

Chan, S. Cheung, \& Lu, T. (2004). Understanding Internet Banking Adoption and Use behavior. A Hong Kong perspective. $J$ of Global Information Management. http://dx.doi.org/10.4018/jgim.2004070102

Chen C.W., Chang, A. \& Alex, K. H. (2006). Evaluation of inference adequacy in cumulative 
logistic regression models. An empirical validation of ISW-ridge relationships, China Ocean, 22 .

Chiang, K.P., \& Dholakia, R.R. (2003). Factors driving consumer intention to shop online. An empirical investigation. J. of consumer psychology, 13(1/2), 177-183.

East, R., (1997). Consumer Behaviour: Advances and Applications in Marketing, Prentice Hall, London.

Ebling, T., (2001). The economics of online banking. Target Marketing; Philadelphia, 24, 67-78.

Elliott, \& Speck, (2005). Factors That Affect Attitude Toward A Retail Web Site, Discussion. 11:22, Online Peer and Editiorial Recommendations.

Gefen, D.E. Karahanna, \& Straub, D.W. (2003). Inexperience and experience with online stores: the importance of TAM and trust. IEEE Transactions on Engineering Management, 50(3), 307-321. http://dx.doi.org/10.1109/TEM.2003.817277

Georgiades, P.J. Dupreez, Downald, B., \& Simintiras, A. (2000). Attitudes toward online purchase behavior: comparing academics, students and others. EBMS Working Paper, 4, 1470-2398.

Ghazali, N., \& Weetman, P. (2006). Perpetuating traditional influences: Voluntary disclosure in Malaysia following the economic crisis. J. International Accounting, Auditing and Taxation, 15(2), 226-248. http://dx.doi.org/10.1016/j.intaccaudtax.2006.08.001

Ginovsky, J., (2001). Bricks can excel at clicks. ABA Bankers News: ashington, 9(8), 17.

Ha, S., \& Stoel, L. (2009). Consumer e-shopping acceptance: Antecedents in a technology acceptance model. J Business Research, 62(5). 565.

Hernandez, J. M. C., \& Mazzon, J.A. (2007). Adoption of internet banking: proposition and implementation of an integrated methodology approach. J. Inte Bank Mark., 25(2), 72-88. http://dx.doi.org/10.1108/02652320710728410

Higgins, A. (2001). Designing with the new Internet. Machine Design, Cleveland, 73(14), 90-94.

Hoffman, D. L., \& Novak, T.P. (2002). A new market for paradigm for electronic commerce. J. Information Society, 13, 43-54.

Hsu, H. (2006). An empirical study of web site quality, customer value, and customer satisfaction based on E-shop. J. The Business Review, 5(1), 190.

Jarvenpaa, S. N. Tractinsky, \& Vitale, M. (2000). Consumer Trust in an Internet Store. J. Information Technology and Management, 1, 45-71. http://dx.doi.org/10.1023/A:1019104520776

Jayawardhena, C. (2004). Personal Values' Influence on e-Shopping Attitude and Behaviour. J. Internet Research, 14, 127-138. http://dx.doi.org/10.1108/10662240410530844 
Joon Moon, B. (2004). Consumer adoption of the internet as an information search and product purchase channel: some research hypotheses. J. International of Internet Marketing and Advertising, 1, 104-118. http://dx.doi.org/10.1504/IJIMA.2004.003692

Kau, K. A., Tang, Y.E., \& Ghose, S. (2003). Typology of Online Shoppers. J. of Consumer Research, 20(2): 139-156.

Keng, C. J. Huang., Zheng, T. L. \& Hsu, M. K. (2007). Modeling service encounters and customer experiential value in retailing An empirical investigation of shopping mall customers in Taiwan. J. International of Service Industry Management, 18.

Kim, S. R. Williams, \& Lee, Y. (2003). Attitude toward online shopping and retail website quality: A comparison of US and Korean consumers. J of International Consumer Marketing. http://dx.doi.org/10.1300/J046v16n01_06

Kotler, P., \& Armstrong, G. (2000). Marketing, 5th Ed., Prentice-Hall: Englewood Cliffs, NJ.

Lee, M., \& Johnson, K. (2002). Exploring difference between Internet apparel purchasers, browsers, and non-purchasers. $J$ of Fashion Marketing and Management, 6(2). http://dx.doi.org/10.1108/13612020210429485

Leo, C., R. Bennett, \& Härtel, C. (2005). Cross-culture differences in consumer Decision-making styles. J. Cross Cultural Management, 12(3), 32-62. http://dx.doi.org/10.1108/13527600510798060

Gefen, D.E. Karahanna, \& Straub, D.W. (2003). Inexperience and experience with online stores: the importance of TAM and trust. IEEE Transactions on Engineering Management, 50(3), 307-321. http://dx.doi.org/10.1109/TEM.2003.817277

Georgiades, P.J. Dupreez, Downald, B. \& Simintiras, A. (2000). Attitudes toward online purchase behavior: comparing academics, students and others. EBMS Working Paper, 4, 1470-2398.

Ghazali, N., \& Weetman, P. (2006). Perpetuating traditional influences: Voluntary disclosure in Malaysia following the economic crisis. J. International Accounting, Auditing and Taxation, 15(2) 226-248. http://dx.doi.org/10.1016/j.intaccaudtax.2006.08.001

Ginovsky, J., (2001). Bricks can excel at clicks. ABA Bankers News: ashington, 9(8), 17.

Ha, S., \& Stoel, L. (2009). Consumer e-shopping acceptance: Antecedents in a technology acceptance model. J Business Research, 62(5), 565.

Hernandez, J. M. C., \& Mazzon, J.A. (2007). Adoption of internet banking: proposition and implementation of an integrated methodology approach, J. Inte Bank Mark. 25(2), 72-88. http://dx.doi.org/10.1108/02652320710728410

Higgins, A. (2001). Designing with the new Internet. Machine Design, Cleveland, 73(14), 90-94.

Hoffman, D. L., \& Novak, T.P. (2002). A new market for paradigm for electronic commerce. J. Information Society, 13, 43-54. 
Hsu, H. (2006). An empirical study of web site quality, customer value, and customer satisfaction based on E-shop. J. The Business Review, 5(1), 190.

Jarvenpaa, S. N. Tractinsky, \& Vitale, M. (2000). Consumer Trust in an Internet Store. J. Information Technology and Management, 1, 45-71. http://dx.doi.org/10.1023/A:1019104520776

Jayawardhena, C. (2004). Personal Values' Influence on e-Shopping Attitude and Behaviour. J. Internet Research, 14, 127-138. http://dx.doi.org/10.1108/10662240410530844

Joon Moon, B. (2004). Consumer adoption of the internet as an information search and product purchase channel: some research hypotheses. J. International of Internet Marketing and Advertising, 1, 104-118.

http://dx.doi.org/10.1504/IJIMA.2004.003692

Kau, K. A., Tang, Y.E. \& Ghose, S. (2003). Typology of Online Shoppers. J. of Consumer Research, 20(2), 139-156.

Keng, C. J. Huang., Zheng, T. L., \& Hsu, M. K. (2007). Modeling service encounters and customer experiential value in retailing An empirical investigation of shopping mall customers in Taiwan. J. International of Service Industry Management, 18.

Kim, S. R. Williams, \& Lee, Y. (2003). Attitude toward online shopping and retail website quality: A comparison of US and Korean consumers. J of International Consumer Marketing. http://dx.doi.org/10.1300/J046v16n01_06

Kotler, P., \& Armstrong, G. (2000). Marketing, 5th Ed., Prentice-Hall: Englewood Cliffs, NJ.

Lee, M. \& Johnson, K. (2002). Exploring difference between Internet apparel purchasers, browsers, and non-purchasers. $J$ of Fashion Marketing and Management, 6(2). http://dx.doi.org/10.1108/13612020210429485

Leo, C., R. Bennett, \& Härtel, C. (2005). Cross-culture differences in consumer Decision-making styles. J. Cross Cultural Management, 12(3), 32-62. http://dx.doi.org/10.1108/13527600510798060

Li, H., Kuo, C., \& Russell, M. G. (1999). The impact of perceived channel utilities, shopping orientations and demographics on the consumer's online buying behavior. J. Computer Mediated Communication, 5, 23-50.

Lim, H. \& Dubinsky, A.F. (2004). Consumers' perceptions of e-shopping characteristics: an expectancy value approach. J. Services Marketing, 18, 500-13. http://dx.doi.org/10.1108/08876040410561839

Lin, C. \& Hong, C. (2006). Using customer knowledge in designing electronic catalog, Expert Systems with Applications: www.elsevier.com/locate/eswa.

Magee, M., (2003). Boom or bust for shopping. The Snday Tribune: http://web.lexisnexis.com/universe/document (Retrieved December 22).

Morimoto, M. \& Chang, S. (2006). Consumers' Attitudes toward Unsolicited Commercial 
E-mail and Postal Direct Mail Marketing Methods: Intrusiveness, Perceived Loss of Control, $\begin{array}{llll}\text { and Irritation. } \quad J . & \text { Interactive } & \text { Advertising, } & 7,\end{array}$ http://dx.doi.org/10.1080/15252019.2006.10722121

Paderni, L. (2005). The web's latest trend fashion. From. http://www.forrester.com/Research/Document/Excerpt/0,7211,37531,00.

Parissa, H. \& Maria, M. (2005). Consumer Attitude toward Advertising via Mobile Devices An Empirical Investigation among Austrian Users. ECIS Proceedings.

Rendleman, J. (2001). Customer data means money, InformationWeek. Manhasset, 851, 49-50.

Schubert, P. \& Dorian, S. (1999). Web Assessment - Measuring the Effectiveness of Electronic Commerce Sites Going beyond Traditional Marketing Paradigms, Proceedings of the Hawaii International Conference on System Sciences.

Sekaran, U., \& Bougie, R. (2010). Research Methods for Business: A Skill Building Approach. UK: John Wiley \& Sons. 7.

Senecal, S. \& Natel, J. (2004). The influence of online product recommendation on consumers online choice, J. Retailing, 80, 159-16. http://dx.doi.org/10.1016/j.jretai.2004.04.001

Shergil, G. \& Chen, Z. (2005). Web-based shopping: consumers' attitudes towards online shopping in New Zealand. J. Electronic Commerce Research, 6(2).

Shim, E., Lotz, S., \& Warrington, P. (2001). An online prepurchase Intentions model: The role of intention to search, J.Retailing, 77, 394-416. http://dx.doi.org/10.1016/S0022-4359(01)00051-3

Smith, A. (2004). Cybercriminal impacts on online business and consumer confidence. $J$. Online Information Review, 28(3), 224-234.

http://dx.doi.org/10.1108/14684520410543670

Teo, T. S. H. (2006). To buy or not to buy online: Adopters and non-adopters of online shopping in Singapore. J. Behaviour \& Information Technology. http://dx.doi.org/10.1080/01449290500256155

Wu, G. (1999). Perceived interactivity and attitude toward website, Annual Conference of American Academy of Advertising Albuquerque, Mexico.

$\mathrm{Wu}, \mathrm{S}$. (2003). The relationship between consumer characteristics and attitude toward online shopping. Marketing Intelligence and Planning, 21(1), 37-44. http://dx.doi.org/10.1108/02634500310458135

Yang, B. \& Lester, D. (2004). Attitudes toward buying online. Cyber Psychology \& Behavior. 7(1), 85-91. 